\title{
QUESTIONNAIRE DESIGN FOR FOOT HEALTH EVALUATION
}

\section{ELABORAREA CHESTIONARULUI PENTRU EVALUAREA SĂNĂTĂTII PICIORULUI}

\author{
Alina IOVAN-DRAGOMIR* \\ “Gheorghe Asachi” Technical University, lasi, 29 D. Mangeron Bd, alina.dragomir@windowslive.com
}

\begin{abstract}
QUESTIONNAIRE DESIGN FOR FOOT HEALTH EVALUATION
ABSTRACT. Feet are the foundation and support of most human activities. Feet problems, even minor ones, influence the ability to work and freedom to do all kinds of activities, limiting individual options and affecting the quality of life. The aim of this study is to apply the principles of contentment and validation in order to develop a new questionnaire specifically designed to measure foot health status. For this, a group of experts was nominated to establish the domains of questionnaire and to develop the specific questions. The items were then evaluated by a validation group. 141 persons evaluated each item. The evaluation gave information about the importance of each domain and the relevance of each question to foot health.

KEYWORDS: pain, life quality, footwear
\end{abstract}

ELABORAREA CHESTIONARULUI PENTRU EVALUAREA SĂNĂTĂTII PICIORULUI

REZUMAT. Picioarele reprezintă baza şi suportul pentru majoritatea activităţilor umane. Problemele picioarelor afectează capacitatea de muncă şi libertatea de a face orice activitate, limitează opţiunile individului şi influenţează calitatea vieţii. Obiectivul acestui studiu este să construiască un chestionar care să evalueze starea de sănătate a picioarelor, aplicând principii de elaborare şi evaluare a conţinutului. În acest sens, un grup de experţi au stabilit domeniile şi ulterior întrebările chestionarului, care au fost apoi evaluate de un grup de validare format din 141 persoane. Evaluarea de către grupul de validare a relevat importanţa fiecărui domeniu asupra sănătăţii piciorului, precum şi relevanţa fiecărei întrebări în parte.

CUVINTE CHEIE: durere, calitatea vieţii, încălţăminte

\section{L'ELABORATION DU QUESTIONNAIRE POUR L'EVALUATION DE LA SANTÉ DU PIED}

RÉSUMÉ. Les pieds représentent le fondement et le soutien pour la majorité des activités humaines. Les problèmes des pieds agissent sur la capacité du travail et sur la liberté de faire n'importe quoi, limitent les options de l'individu et influencent la qualité de la vie. L'objectif de cette étude est de développer un questionnaire qui peut évaluer l'état de santé des pieds, en appliquant les principes d'élaboration et d'évaluation du contenu. A cet égard, un group des experts ont établi les domaines et puis les questions de cet exposé qui, par la suite, ont été évaluées par un group d'évaluation formé par 141 personnes. L'évaluation faite par le group de validation a révélée l'importance de chaque domaine pour la santé du pied, aussi comme la pertinence de chaque question.

MOTS CLÉS: douleur, qualité de la vie, chaussures

\section{INTRODUCTION}

Questionnaires are important tools in foot heath evaluation. Generally speaking, the questionnaires are based on identification and understanding of the sensations in the feet.

Frequently, foot discomfort can be a sign of foot affections (corns, ingrown nails, flat foot, finger deformities) or a sign of systemic diseases (rheumatoid arthritis, lupus), metabolic diseases (diabetes, gout), vascular or neural diseases (angiopathies, neuropathies).

In rheumatoid arthritis, for example, the foot is frequently the first affected area, so by the time the diagnostic is determined, approximately $16 \%$ of the patients already have the foot affected. This percentage increases up to $100 \%$ for the patients affected by one of these diseases for longer than 10 years [1].

\section{INTRODUCERE}

În evaluarea stării de sănătate a piciorului un rol important îl au chestionarele care se bazează, în general, pe izolarea şi clarificarea senzaţiilor percepute de purtător.

Adesea starea de disconfort resimţită de picior poate fi un semn al unei afecţiuni a piciorului (bătături, unghii încarnate, platfus, deformări ale degetelor etc.) sau un simptom al unei boli sistemice (artrita reumatoidă), metabolice (diabetul, guta), vasculare sau neuronale (neuropatii).

De exemplu, în artrita reumatoidă, adesea, piciorul este prima zonă afectată, astfel că, până la diagnosticare, aproximativ $16 \%$ din pacienţi au piciorul afectat, iar procentul creşte până la $100 \%$ pentru cei bolnavi de peste 10 ani [1]. 
The most frequent gout symptoms are: inflammation, pain, swelling and stiffness of affected joint. The initial manifestation of gout is usually an acute attack of peripheral joints, most commonly the hallux, for $56-78 \%$ of patients [2]. However, $59-89 \%$ of the gout patients have this joint affected [3], while for $25-50 \%$ the knee and ankle are affected.

Peripheral neuropathy caused by diabetes leads to losing the sensation of pain, as well as touch, thermal and vibration perception. Among diabetic patients, approximately $23-42 \%$ have peripheral neuropathy and the rate increases up to $50-60 \%$ for patients with diabetes type 2 [4]. For $75-80 \%$ of the patients, the abnormal running of the peripheral nervous system is announced by several symptoms, such as: burning sensation, pins and needles in the feet, sharp and stabbing pain and muscle cramps.

Several questionnaires were designed in the last decades which can help evaluate and measure the feet health. A group of questionnaires are included in specific heath evaluation systems such as Arthritis Impact Measurement [5, 6], Sickness Impact Profile [7], Foot Function Index [8], American Academy of Orthopaedic Surgeons Lower Limb Outcomes Assessment Instruments: Foot and Ankle Questionnaire [9], Western Ontario and McMaster University Osteoarthritis Index (WOMAC) [10], and McGill Pain Questionnaire [11]. Other questionnaires are used in measuring general health, such as Foot Health Status Questionnaire (FHSQ) [12] and Podiatry Health Questionnaire [13], while a third group measures the impact of feet problems on life quality (the Bristol Foot Score [1]) or the comfort provided by footwear (the Shoe Comfort Scale).

To a certain degree, the objective of all of these questionnaires is the recognition and quantification of the different types of feet discomfort felt by the patient caused by pain, a poor functioning of the foot, foot aspect, its general health, and by its interaction with shoes, all analyzed in static and dynamic, over a certain period of time.

\section{METHOD USED}

A focus group of ten experts composed of five physicians (a diabetologist, an endocrinologist and three orthopaedists) and five experts in shoe design
Simptomele gutei cel mai frecvent întâlnite sunt inflamarea, durerea, umflarea şi rigiditatea articulaţiilor afectate. La 56-78\% din pacienţi [2], primul atac de gută afectează haluxul, la 59-89\% din pacienţi această articulaţie este afectată [3], iar 25-50\% din pacienţi au afectate articulaţiile genunchiului şi gleznei.

Neuropatia periferică datorată diabetului duce la pierderea sensibilităţii dureroase, tactile, termice şi vibratorii. Dintre persoanele cu diabet aproximativ 23-42\% prezintă neuropatie, iar la pacienţii cu diabet de tip 2 procentul creşte până la 50-60\% [4]. La 75$80 \%$ din pacienţi funcţionarea anormală a sistemului nervos periferic este anunţată de o serie de simptome, cum ar fi: senzaţie de fierbinţeală, înţepături, ace la nivelul plantei, dar şi crampe musculare şi puseuri dureroase.

Au fost concepute chestionare cu ajutorul cărora poate fi evaluată şi măsurată starea de sănătate a piciorului, specifice diferitor afecţiuni, cum ar fi Măsurarea Impactului Artritic (Arthritis Impact Measurement [5, 6]), Sickness Impact Profile [7], Indexul de Funcţionare al Piciorului (Foot Function Index [8]), Indexul Osteoartritic al Universităţilor McMaster şi Western Ontario (Western Ontario and McMaster University Osteoarthritis Index (WOMAC) [9]), Chestionarul McGill pentru Durere (McGill Pain Questionnaire [10]), dar şi chestionare care evaluează starea de sănătate generală, Foot Health Status Questionnaire (FHSQ) [12] şi Podiatry Health Questionnaire [13], impactul asupra calitatea vieţii (Bristol Foot Score [1]), confortul oferit de încălţăminte (The Shoe Comfort Scale) etc.

Într-un procent mai mare sau mai mic, aceste chestionare urmărescidentificarea şi cuantificarea tipului de disconfort resimţit de pacient şi care poate fi dat de durere, de o funcţionare deficitară a piciorului, de aspectul piciorului, de starea generală de sănătate a acestuia, precum şi de interacţiunea cu încălţămintea, toate analizate în statică şi dinamică, pe un anumit interval de timp.

\section{METODE}

În vederea elaborării întrebărilor chestionarului privind Evaluarea Sănătăţii Piciorului (ESP) s-a alcătuit un grup format din zece experţi: cinci medici (un 
and technology was created in order to develop the questions regarding Health Foot Evaluation (ESP). The first task of the group was to identify the most relevant perceptions and to associate them with a certain type of discomfort: tactile, visual, olfactory or acoustic.

Those uncomfortable sensations were grouped in five domains: Symptoms, Pain, Function, Footwear and Quality of life. For the Function domain, two groups of questions were considered: a group for normal activities (named Function 1) and another group for sport activities (called Function 2). Using the Brainstorming method, several questions were established for each domain, 53 questions resulting in the end (Table 1). diabetolog, un endocrinolog şi trei ortopezi) şi cinci specialişti în proiectarea şi fabricarea încălţămintei. Prima sarcină a fost aceea a identificării celor mai relevante senzaţii percepute la nivelul piciorului şi asocierii cu un anumit tip de disconfort tactil, vizual, olfactiv sau auditiv.

Aceste senzaţii de disconfort au fost grupate în cinci teme: Simptome, Durere, Capacitate funcţională, Încălţăminte şi Calitatea vieţii. Pentru tema Capacitate funcţională, întrebările au fost împărţite în două grupuri: un grup de întrebări se referă la activităţi normale (numit Capacitate funcţională 1) şi celălalt grup la activităţi sportive (numit Capacitate funcţională 2). Pentru fiecare dintre teme au fost elaborate mai multe întrebări, prin metoda Brainstorming, rezultând în final un număr de 53 de întrebări (Tabelul 1).

Table 1: Structure of the questionnaire

Tabelul 1: Structura chestionarului

\begin{tabular}{|c|c|c|c|}
\hline $\begin{array}{l}\text { Domain } \\
\text { Temă }\end{array}$ & $\begin{array}{l}\text { Questions } \\
\text { Intrebare }\end{array}$ & $\begin{array}{l}\text { Code } \\
\text { Cod }\end{array}$ & $\begin{array}{l}\text { No. of questions } \\
\text { Nr. întrebări }\end{array}$ \\
\hline \multirow{7}{*}{$\begin{array}{l}\text { Symptom } \\
\text { Simptome }\end{array}$} & $\begin{array}{l}\text { Do you have swelling in your foot? } \\
\text { Vi se umflă piciorul? }\end{array}$ & S1 & \multirow{7}{*}{7} \\
\hline & $\begin{array}{l}\text { Do you hear noises when your feet move? } \\
\text { in timpul mersului, apar zgomote la nivelul articulaţiilor? }\end{array}$ & S2 & \\
\hline & $\begin{array}{l}\text { Do you have muscle cramps when your feet move? } \\
\text { in timpul mersului, apar crampe musculare? }\end{array}$ & S3 & \\
\hline & $\begin{array}{l}\text { Do you experience rich sweat in your foot? } \\
\text { Vă transpiră abundent piciorul? }\end{array}$ & S4 & \\
\hline & $\begin{array}{l}\text { Do you have burning sensations in your feet? } \\
\text { Aveţi senzaţie de fierbinţeală la nivelul piciorului? }\end{array}$ & S5 & \\
\hline & $\begin{array}{l}\text { Do you have corns? } \\
\text { Aveţi bătături? }\end{array}$ & S6 & \\
\hline & $\begin{array}{l}\text { Is the shape of your foot modified? } \\
\text { Forma piciorului este modificată? }\end{array}$ & S7 & \\
\hline \multirow{5}{*}{$\begin{array}{l}\text { Pain } \\
\text { Durere }\end{array}$} & $\begin{array}{l}\text { How often do you experience foot pain? } \\
\text { Cât de des te doare piciorul? }\end{array}$ & D1 & \multirow{5}{*}{9} \\
\hline & $\begin{array}{l}\text { Which is the intensity of pain when twisting/pivoting on your foot? } \\
\text { Care este intensitatea durerii resimţite la răsucirea/pivotarea piciorului? }\end{array}$ & D2 & \\
\hline & $\begin{array}{c}\text { Which is the intensity of pain when fully stretching the foot? } \\
\text { Care este intensitatea durerii resimţite la întinderea completă a } \\
\text { piciorului? }\end{array}$ & D3 & \\
\hline & $\begin{array}{l}\text { Which is the intensity of pain when fully bending the foot? } \\
\text { Care este intensitatea durerii resimţite la flexia completă a piciorului? }\end{array}$ & D4 & \\
\hline & $\begin{array}{l}\text { Which is the intensity of pain when walking on flat surfaces? } \\
\text { Care este intensitatea durerii resimţite la deplasarea pe o suprafaţă } \\
\text { dreaptă? }\end{array}$ & D5 & \\
\hline
\end{tabular}


Table 1: Continued

Tabelul 1: Continuare

\begin{tabular}{|c|c|c|c|}
\hline $\begin{array}{l}\text { Domain } \\
\text { Temă }\end{array}$ & $\begin{array}{l}\text { Questions } \\
\text { Întrebare }\end{array}$ & $\begin{array}{l}\text { Code } \\
\text { Cod }\end{array}$ & $\begin{array}{l}\text { No. of questions } \\
\text { Nr. întrebări }\end{array}$ \\
\hline \multirow{4}{*}{$\begin{array}{l}\text { Pain } \\
\text { Durere }\end{array}$} & $\begin{array}{l}\text { Which is the intensity of pain when going up or down the stairs? } \\
\text { Care este intensitatea durerii resimţite la urcatul sau coborâtul scărilor? }\end{array}$ & D6 & \multirow{4}{*}{9} \\
\hline & $\begin{array}{l}\text { Which is the intensity of pain during night sleep? } \\
\text { Care este intensitatea durerii resimţite noaptea, în timpul somnului? }\end{array}$ & D7 & \\
\hline & $\begin{array}{l}\text { Which is the intensity of pain during sitting or lying? } \\
\text { Care este intensitatea durerii resimţite în repaus, pe scaun sau în pat? }\end{array}$ & D8 & \\
\hline & $\begin{array}{l}\text { Which is the intensity of pain after a day of work? } \\
\text { Care este intensitatea durerii resim ţite la sfârşitul zilei de muncă? }\end{array}$ & D9 & \\
\hline \multirow{13}{*}{$\begin{array}{l}\text { Function } 1 \\
\text { Capacitatea } \\
\text { funcţională } 1\end{array}$} & $\begin{array}{l}\text { Are you able to stretch your foot fully? } \\
\text { Poţi întinde complet piciorul? }\end{array}$ & C1 & \multirow{13}{*}{22} \\
\hline & $\begin{array}{l}\text { Are you able to bend your foot fully? } \\
\text { Poţi flexa complet piciorul? }\end{array}$ & C2 & \\
\hline & $\begin{array}{l}\text { Which is the degree of difficulty you have experienced when sitting? } \\
\text { Care este gradul de dificultate resimţit la statul pe scaun? }\end{array}$ & C3 & \\
\hline & $\begin{array}{l}\text { Which is the degree of difficulty you have experienced when standing? } \\
\text { Care este gradul de dificultate resimţit la statul în picioare? }\end{array}$ & C4 & \\
\hline & $\begin{array}{l}\text { How severe is your foot stiffness after waking up in the morning? } \\
\text { Dimineaţa, când faci primii paşi, piciorul este rigid? }\end{array}$ & C5 & \\
\hline & $\begin{array}{l}\text { How severe is your foot stiffness after resting, sitting or lying later in } \\
\text { the day? } \\
\text { Cât de severă este rigiditatea picorului spre sfârşitul zilei după ce te } \\
\text { odihneşti stând pe scaun sau culcat? }\end{array}$ & C6 & \\
\hline & $\begin{array}{l}\text { Which is the degree of difficulty you have experienced when going } \\
\text { downstairs? } \\
\text { Care este gradul de dificultate resimţit la coborâtul scărilor? }\end{array}$ & C7 & \\
\hline & $\begin{array}{c}\text { Which is the degree of difficulty you have experienced when going } \\
\text { upstairs? } \\
\text { Care este gradul de dificultate resimţit la urcatul scărilor? }\end{array}$ & C8 & \\
\hline & $\begin{array}{l}\text { Which is the degree of difficulty you have experienced when rising from } \\
\text { sitting? } \\
\text { Care este gradul de dificultate resimtit la ridicatul de pe scaun? }\end{array}$ & C9 & \\
\hline & $\begin{array}{l}\text { Which is the degree of difficulty you have experienced when bending to } \\
\text { the floor to pick up an object? } \\
\text { Care este gradul de dificultate resimţit la aplecarea însoţită de ridicarea } \\
\text { unui obiect? }\end{array}$ & C10 & \\
\hline & $\begin{array}{l}\text { Which is the degree of difficulty you have experienced when walking on } \\
\qquad \text { flat surfaces? } \\
\text { Care este gradul de dificultate resimţit la mers, pe o suprafaţă dreaptă? }\end{array}$ & C11 & \\
\hline & $\begin{array}{l}\text { Which is the degree of difficulty you have experienced when getting } \\
\text { in/out of the car? } \\
\text { Care este gradul de dificultate resimţit la urcatul/coborâtul din maşină? }\end{array}$ & C12 & \\
\hline & $\begin{array}{c}\text { Which is the degree of difficulty you have experienced when standing } \\
\text { on tiptoes? } \\
\text { Care este gradul de dificultate resimţit la ridicarea pe vârfuri? }\end{array}$ & C13 & \\
\hline
\end{tabular}


Table 1: Continued

Tabelul 1: Continuare

\begin{tabular}{|c|c|c|c|}
\hline $\begin{array}{l}\text { Domain } \\
\text { Temă }\end{array}$ & $\begin{array}{l}\text { Questions } \\
\text { Intrebare }\end{array}$ & $\begin{array}{l}\text { Code } \\
\text { Cod }\end{array}$ & $\begin{array}{l}\text { No. of questions } \\
\text { Nr. întrebări }\end{array}$ \\
\hline \multirow{9}{*}{$\begin{array}{l}\text { Function } 1 \\
\text { Capacitatea } \\
\text { funcţională } 1\end{array}$} & $\begin{array}{c}\text { Which is the degree of difficulty you have experienced putting } \\
\text { on/taking off the socks? } \\
\text { Care este gradul de dificultate resimţit la îmbrăcat/dezbrăcat şosete? }\end{array}$ & C14 & \multirow{9}{*}{22} \\
\hline & $\begin{array}{l}\text { Which is the degree of difficulty you have experienced rising from bed? } \\
\text { Care este gradul de dificultate resimţit la ridicatul din pat? }\end{array}$ & C15 & \\
\hline & $\begin{array}{c}\text { Which is the degree of difficulty you have experienced when going up a } \\
\text { slope? } \\
\text { Care este gradul de dificultate resimţit la urcarea unei pante? }\end{array}$ & C16 & \\
\hline & $\begin{array}{l}\text { Which is the degree of difficulty you have experienced when going } \\
\text { down a slope? } \\
\text { Care este gradul de dificultate resimţit la coborârea unei pante? }\end{array}$ & C17 & \\
\hline & $\begin{array}{c}\text { Which is the degree of difficulty you have experienced when you are } \\
\text { lying in bed? } \\
\text { Care este gradul de dificultate resimţit când te întinzi în pat? }\end{array}$ & C18 & \\
\hline & $\begin{array}{l}\text { Which is the degree of difficulty you have experienced when getting } \\
\text { in/out the bathtub? } \\
\text { Care este gradul de dificultate resimţit la intratul/ieşitul din cadă? }\end{array}$ & C19 & \\
\hline & $\begin{array}{c}\text { Which is the degree of difficulty you have experienced when getting } \\
\text { on/off the toilet? } \\
\text { Care este gradul de dificultate resimţit la aşezatul/ridicatul de pe } \\
\text { toaletă? }\end{array}$ & $\mathrm{C} 20$ & \\
\hline & $\begin{array}{l}\text { Which is the degree of difficulty you have experienced when doing } \\
\text { heavy domestic duties (moving heavy boxes, scrubbing floor, etc.)? } \\
\text { Care este gradul de dificultate resimţit în timpul efectuării activităţilor } \\
\text { domestice grele (ridicarea unor cutii grele, curăţarea podelelor)? }\end{array}$ & $\mathrm{C} 21$ & \\
\hline & $\begin{array}{l}\text { Which is the degree of difficulty you have experienced when doing light } \\
\text { domestic duties (cooking, dusting, etc.)? } \\
\text { Care este gradul de dificultate resimţit în timpul efectuării activităţilor } \\
\text { domestice uşoare (gătit, curăţenie, etc.)? }\end{array}$ & $\mathrm{C} 22$ & \\
\hline \multirow{6}{*}{$\begin{array}{l}\text { Function } 2 \\
\text { Capacitatea } \\
\text { funcţională } 2\end{array}$} & $\begin{array}{c}\text { Which is the degree of difficulty you have experienced when doing } \\
\text { squatting? } \\
\text { Care este gradul de dificultate resimţit la efectuarea exerciţiilor din } \\
\text { ghemuit? }\end{array}$ & Sp1 & \multirow{6}{*}{6} \\
\hline & $\begin{array}{l}\text { Which is the degree of difficulty you have experienced when running? } \\
\text { Care este gradul de dificultate resimţit la alergare? }\end{array}$ & Sp2 & \\
\hline & $\begin{array}{c}\text { Which is the degree of difficulty you have experienced when jumping? } \\
\text { Care este gradul de dificultate resimţit la efectuarea săriturilor? }\end{array}$ & Sp3 & \\
\hline & $\begin{array}{l}\text { Which is the degree of difficulty you have experienced if you are } \\
\text { turning/twisting your foot? } \\
\text { Care este gradul de dificultate resimţit la întoarcere/răsucire pe un } \\
\text { picior? }\end{array}$ & Sp4 & \\
\hline & $\begin{array}{l}\text { Which is the degree of difficulty you have experienced when doing } \\
\text { exercises in kneeling position? } \\
\text { Care este gradul de dificultate resimţit la efectuarea exerciţiilor în } \\
\text { ingenunchiat? }\end{array}$ & Sp5 & \\
\hline & $\begin{array}{l}\text { Which is the degree of difficulty you have experienced when doing } \\
\text { lunge exercises? } \\
\text { Care este gradul de dificultate resimţit la efectuarea fandărilor? }\end{array}$ & Sp6 & \\
\hline
\end{tabular}


Table 1: Continued

Tabelul 1: Continuare

\begin{tabular}{|c|c|c|c|}
\hline $\begin{array}{l}\text { Domain } \\
\text { Temă }\end{array}$ & $\begin{array}{l}\text { Questions } \\
\text { Întrebare }\end{array}$ & $\begin{array}{l}\text { Code } \\
\text { Cod }\end{array}$ & $\begin{array}{l}\text { No. of questions } \\
\text { Nr. întrebări }\end{array}$ \\
\hline \multirow{4}{*}{$\begin{array}{l}\text { Footwear } \\
\text { Încălţăminte }\end{array}$} & $\begin{array}{l}\text { Do you have dificulties finding comfortable shoes? } \\
\text { Este dificil să vă găsiţi încălţăminte care să nu vă deranjeze? }\end{array}$ & 11 & \multirow{4}{*}{4} \\
\hline & $\begin{array}{l}\text { Do you have dificulties finding shoes that fit you? } \\
\text { Este dificil să vă găsiţi încălţăminte care să vi se potrivească } \\
\text { dimensional? }\end{array}$ & 12 & \\
\hline & $\begin{array}{l}\text { Are you hampered by your shoes? } \\
\text { Sunteţi deranjat de încălţămintea pe care trebuie să o purtaţi? }\end{array}$ & 13 & \\
\hline & $\begin{array}{l}\text { What types of shoes are comfortable when wearing? } \\
\text { Ce tip de încălţăminte vă este confortabil? }\end{array}$ & 14 & \\
\hline \multirow{5}{*}{$\begin{array}{l}\text { Quality of life } \\
\text { Calitatea vieţii }\end{array}$} & $\begin{array}{l}\text { How of ten are you aware of your foot problems? } \\
\text { De câte ori aţi conştientizat problemele piciorului? }\end{array}$ & Q1 & \multirow{5}{*}{5} \\
\hline & $\begin{array}{l}\text { Have you modified your daily program to avoid potentially damaging } \\
\text { activities to your foot? } \\
\qquad \begin{array}{l}\text {-aţi schimbat programul zilnic pentru a evita activităţile ce vă } \\
\text { afectează piciorul? }\end{array}\end{array}$ & Q2 & \\
\hline & $\begin{array}{c}\text { How troubled are you by the lack of confidence in your foot? } \\
\text { Cât de afectat sunteţi de faptul că nu vă puteţi baza pe piciorul } \\
\text { dumneavoastră? }\end{array}$ & Q3 & \\
\hline & $\begin{array}{l}\text { In general, how much difficulty do you have because of your feet? } \\
\text { În general, cât de multe dificultăţi întâmpinaţi din cauza piciorului? }\end{array}$ & Q4 & \\
\hline & $\begin{array}{l}\text { Do you feel uncomfortable with your foot appearance and shape? } \\
\text { Sunteţi jenat de aspectul piciorului dumneavoastră? }\end{array}$ & Q5 & \\
\hline
\end{tabular}

In the second stage of the ESP design, all those questions were validated by 141 members of a group composed of women and men, aged between 20 and 70 years (Table 2 ), well educated and active on the labour market. Individually, they decidedabout relevance/irrelevance of eachquestion.
În a doua etapă, aceste întrebări au fost supuse validării unui grup de 141 de persoane, bărbaţi şi femei, cu vârste între 20 şi 70 de ani (Tabelul 2), cu studii superioare şi active, care au decis, în mod individual cu privire la relevanţa sau irelevanţa fiecărei întrebări în parte.

Table 2: Demographic characteristics of the group

Tabelul 2: Caracteristici demografice ale populaţiei studiate

\begin{tabular}{|c|c|c|c|}
\hline $\begin{array}{c}\text { Age (years) } \\
\text { Vârsta (ani) }\end{array}$ & $\begin{array}{c}\text { \% from all } \\
\text { \% din total }\end{array}$ & $\begin{array}{c}\text { Men } \\
\text { Bărbaţi }\end{array}$ & $\begin{array}{c}\text { Women } \\
\text { Femei }\end{array}$ \\
\hline $20-30$ & 17.02 & $50 \%$ & $50 \%$ \\
\hline $30-40$ & 29.78 & $28 \%$ & $72 \%$ \\
\hline $40-50$ & 27.66 & $30 \%$ & $70 \%$ \\
\hline $50-60$ & 17.02 & $37 \%$ & $63 \%$ \\
\hline $60-70$ & 8.52 & $50 \%$ & $50 \%$ \\
\hline
\end{tabular}

In the third stage, all answers were reviewed and the judged with regard to their relevance - a questionnaire was considered irrelevant if it contained
În cea de a treia etapă, toate răspunsurile au fost analizate din punctul de vedere al relevanţei - un chestionar a fost considerat irelevant dacă erau 
unanswered questions or answers with both options selected. In the end, $78.72 \%$ of questionnaires were deemed relevant and kept for analysis.

\section{RESULTS AND DISCUSSIONS}

The first analysis and discussion is about the importance of the domains. The domain importance was calculated with the following relation:

$$
I_{d}=\frac{\sum_{i=1}^{n} \frac{V_{V}}{V_{T}} \cdot 100}{n}
$$

where: Id - domain importance, $V v$ - votes for validation, $\mathrm{Vt}$ - total votes, and $\mathrm{n}$ - number of questions perdomain.

Analyzing the chart from Figure 1, it is somehow surprising but the most relevant domain for foot health is Function 2. The questions for Function 2 regard the physical function of the subject when he/she is active on a higher level during sports and recreational activities.

An explanation for the score determined for domain Function 2 could be the selection criteria defined by the members of the validation group persons that are active on the labour market. Normally, their activities have a higher level of difficulty.

Furthermore, when comparing Function 1 with Function 2, the higher score of the second function domain can be the result of very clear, simple, concise and well applied questions. Function 1 domain includes questions about the ability to move around and carry out daily activities.

This domain had the highest number of removed questions. When evaluating the domain without the removed questions, its importance increased to over $62 \%$. întrebări neevaluate sau la care ambele opţiuni, relevant/irelevant, erau bifate. În final au rămas în analiză $78.72 \%$ din chestionare.

\section{REZULTATE ŞI DISCUTII}

O primă analiză care se face este cea referitoare la importanţa domeniilor. Importanţa domeniului a fost calculată cu relaţia:

unde: Id - importanţa domeniului, $\mathrm{V} v$ - voturi pentru validare, $\mathrm{Vt}$ - totalul voturilor exprimate, $\mathrm{n}$ - numărul de întrebări din domeniu.

Analizând graficul din Figura 1, în mod oarecum surprinzător se constată că cea mai mare relevanţă pentru sănătatea piciorului o prezintă „Capacitate funcţională 2", care se referă la capacitatea de funcţionare a organismului în timpul desfăşurării unor activităţi cu grad de dificultate mai ridicat, în timpul activităţilor recreative şi sportive.

Explicaţia poziţionării acestui domeniu pe primul loc stă în unul dintre criteriile de selecţie ale membrilor grupului de validare, respectiv, persoane active pe piaţa muncii, care în mod periodic sunt confruntate cu necesitatea desfăşurării unor activităţi cu grad de dificultate ridicat.

Totodată, procentul ridicat obţinut de acest domeniu poate fi datorat şi formulării mai clare şi mai aplicate a întrebărilor, comparativ cu domeniul "Capacitate funcţională 1 " care se referă la capacitatea de a te mişca şi de a-ţi purta de grijă.

Cele mai multe întrebări eliminate au fost din acest domeniu şi prin eliminarea lor şi importanţa acestuia creşte peste $62 \%$. 


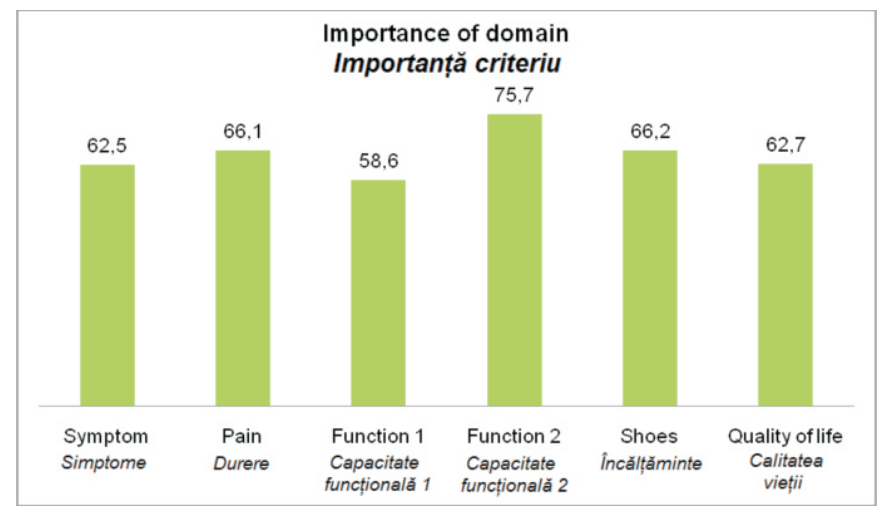

Figure 1. Impact assessment of the domains for the health foot status

Figura 1. Importanţa criteriilor pentru starea de sănătate a piciorului

Each question received a score and was accepted if its level of relevance exceeded $40 \%$. If a question was considered irrelevant for more than $40 \%$ of the participants, then that question did not pass validation and was removed.
În etapa a doua a analizei, se evaluează scorul obţinut de fiecare întrebare în parte. Pentru ca o întrebare să fie considerată validată, trebuie să depăşească un prag de validare de minim $40 \%$. Dacă o întrebare este considerată irelevantă de $40 \%$ din participanţii la studiu, atunci acea întrebare nu trece testul de validare şi va fi eliminată.

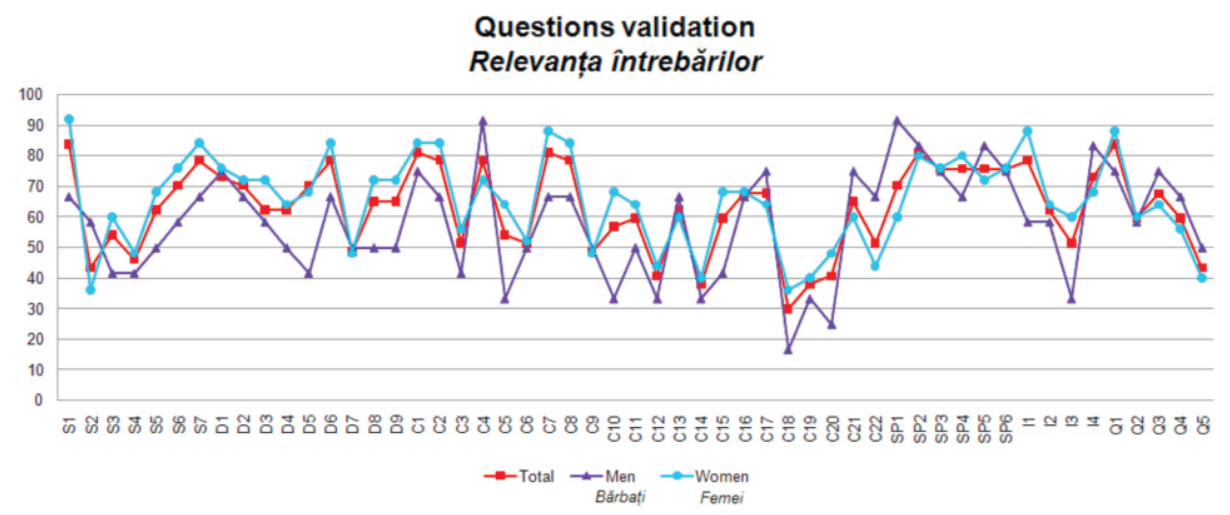

Figure 2. Results of the validation process

Figura 2. Rezultatul procesului de validare

As seen in Figure 2, only 3 questions, C14, C18 and $\mathrm{C} 19$, were removed because they were found irrelevant for the evaluation of the foot health. Also, only men found some of the questions ( $C 5, C 10, C 12, C 20$, and $\mathrm{I} 3$ ) to be irrelevant. The relevancy and subsequent validation of those questions was confirmed by the female participants. A similar situation happened for questions S2 and Q5, found irrelevant by women and validated by the answers of the male participants. The final situation for each domain is presented in Table 3 .
După cum se observă din Figura 2, doar 3 întrebări, C14, C18 şi C19, vor fi eliminate din chestionar, fiind considerate irelevante pentru aprecierea sănătăţii piciorului. Totodată, se remarcă faptul că o serie de întrebări au fost considerate irelevante pentru bărbaţi $(C 5, C 10, C 12, C 20,13)$, dar au fost "salvate" de femei, precum şi situaţia inversă, în care întrebările S2 şi Q5 au fost „salvate” de bărbaţi. În final, situaţia pe criterii este prezentată în Tabelul 3. 
Table 3: The six basic domains of foot health as evaluated by ESP

Tabelul 3: Cele şase criterii ale sănătăţii piciorului evaluate prin ESP

\begin{tabular}{|c|c|c|c|c|}
\hline $\begin{array}{l}\text { Domain } \\
\text { Criteriu }\end{array}$ & $\begin{array}{l}\text { No. of } \\
\text { items } \\
\text { Nr. } \\
\text { întrebări }\end{array}$ & $\begin{array}{c}\text { Theoretical construct } \\
\text { Conceptul teoretic }\end{array}$ & $\begin{array}{l}\text { Meaning of lowest score } \\
\text { Semnificaţia scorului } \\
\text { minim }\end{array}$ & $\begin{array}{l}\text { Meaning of highest score } \\
\text { Semnificaţia scorului } \\
\text { maxim }\end{array}$ \\
\hline $\begin{array}{l}\text { Symptom } \\
\text { Simptome }\end{array}$ & 7 & $\begin{array}{l}\text { Self perception and evaluation of } \\
\text { feet in terms of shape, } \\
\text { appearance and perception } \\
\text { Autoevaluarea picioarelor din } \\
\text { punctul de vedere al formei, } \\
\text { aspectului şi senzatiilor }\end{array}$ & $\begin{array}{l}\text { Self perception that the feet } \\
\text { are in very good state of } \\
\text { health } \\
\text { Stare de sănătate perfectă }\end{array}$ & $\begin{array}{l}\text { Self perception that } \\
\text { the feet are in a poor state } \\
\text { of health and identifies few } \\
\text { symptoms } \\
\text { Înţelegerea stării precare } \\
\text { de sănătate in care se află } \\
\text { picioarele şi identificarea } \\
\text { anumitor simptome }\end{array}$ \\
\hline $\begin{array}{l}\text { Pain } \\
\text { Durere }\end{array}$ & 9 & $\begin{array}{l}\text { Evaluation of feet pain in terms } \\
\text { of type of pain, intensity and } \\
\text { frequency } \\
\text { Evaluarea durerii resimţite la } \\
\text { nivelul extremităţii membrului } \\
\text { inferior, în termeni de: tip de } \\
\text { durere, intensitate şi frecvenţă }\end{array}$ & $\begin{array}{l}\text { No pain at all } \\
\text { Fără dureri }\end{array}$ & $\begin{array}{c}\text { Extreme pain that is acute } \\
\text { in nature } \\
\text { Dureri extreme }\end{array}$ \\
\hline $\begin{array}{l}\text { Function } 1 \\
\text { Capacitate } \\
\text { funţională } 1\end{array}$ & 19 & $\begin{array}{l}\text { Evaluation of feet during daily } \\
\text { activities in terms of impact on } \\
\text { physical function } \\
\text { Evaluarea capacităţii funcţionale } \\
\text { a picioarelor în condiţiile impuse } \\
\text { de traiul zilnic }\end{array}$ & $\begin{array}{c}\text { Can perform all types of } \\
\text { activities without difficulties } \\
\text { or complaints } \\
\text { Pot fi îndeplinite toate } \\
\text { sarcinile fără dificultate sau } \\
\text { durere }\end{array}$ & $\begin{array}{l}\text { Extreme difficulties in the } \\
\text { normal function of feet, } \\
\text { affecting the daily activities } \\
\text { Dificultate extremă în } \\
\text { funcţionarea normală a } \\
\text { piciorului care poate } \\
\text { schimba programul zilnic }\end{array}$ \\
\hline $\begin{array}{l}\text { Function } 2 \\
\text { Capacitate } \\
\text { funţională } 2\end{array}$ & 6 & $\begin{array}{c}\text { Evaluation of feet in terms of } \\
\text { being active at a higher level } \\
\text { such as sports and recreational } \\
\text { activities } \\
\text { Evaluarea capacităţii funcţionale } \\
\text { a picioarelor în condiţiile impuse } \\
\text { de un nivel ridicat de efort, în } \\
\text { timpul activităţilor sportive şi } \\
\text { recreative }\end{array}$ & $\begin{array}{l}\text { Can perform all types of } \\
\text { activities without difficulties } \\
\text { or complaints } \\
\text { Pot fi desfăşurate toate } \\
\text { tipurile de activităţi }\end{array}$ & $\begin{array}{l}\text { Extreme difficulties in } \\
\text { performing sports and } \\
\text { recreational activities } \\
\text { Dificultate extremă în } \\
\text { desfăşurarea activităţilor } \\
\text { sportive sau recreative }\end{array}$ \\
\hline $\begin{array}{l}\text { Footwear } \\
\text { Încălţăminte }\end{array}$ & 4 & $\begin{array}{l}\text { Life-style issues related to } \\
\text { footwear and feet } \\
\text { Stilul de viaţă raportat la } \\
\text { încălţăminte şi picior }\end{array}$ & $\begin{array}{l}\text { No problem with choosing } \\
\text { suitable footwear } \\
\text { Nicio dificultate în alegerea } \\
\text { încălţămintei potrivite }\end{array}$ & $\begin{array}{l}\text { Extremely limited options } \\
\text { in selecting suitable } \\
\text { footwear } \\
\text { Opţiuni extrem de limitate } \\
\text { în achiziţionarea } \\
\text { încălţămintei potrivite }\end{array}$ \\
\hline $\begin{array}{l}\text { Quality of } \\
\quad \text { life } \\
\text { Calitatea } \\
\text { vieţii }\end{array}$ & 5 & $\begin{array}{l}\text { Impact of feet problem, in terms } \\
\text { of activities and life-style } \\
\text { limitations, on the quality of life } \\
\text { Impactul problemelor picioarelor } \\
\text { asupra calităţii vieţii, din punctul } \\
\text { de vedere al limitării activităţii şi } \\
\text { modificării stilului de viaţă }\end{array}$ & $\begin{array}{l}\text { Foot health has no impact on } \\
\text { the life quality } \\
\text { Sănătatea picioarelor nu are } \\
\text { impact asupra calităţii vieţii }\end{array}$ & $\begin{array}{l}\text { Feet health and specific } \\
\text { conditions have a major } \\
\text { impact on the quality of life } \\
\text { Sănătatea picioarelor } \\
\text { influenţează în mod major } \\
\text { calitatea vieţii }\end{array}$ \\
\hline
\end{tabular}

To complete the questionnaire protocol, a method of answering the questions is adopted: using a 5-point Likert scale, from lowest to highest score. Each level on the scale is assigned a numeric value, starting from 0 and increasing by 1 for each level.

Pentru a finaliza etapa de concepere a chestionarului se adoptă modalitatea de răspuns la întrebări, prin intermediul unei scări Likert în 5 puncte, de la semnificaţia scorului minim la semnificaţia scorului maxim. Fiecărui nivel al scării i se alocă o valoare numerică, începând cu 0 şi crescând cu un punct pentru fiecare nivel. 
Interpretation of the questionnaire results is linked to the general score which can be placed between 0 and 100. A low score, as close as possible to 0 , indicates a very good foot health status, while a high score, close to 100 , indicates serious health problems. Subscale calculations for each domain can offer information about the type of foot problems.

\section{CONCLUSIONS}

In conclusion, the ESP questionnaire is a useful instrument in foot health evaluation. Also, it can be used for the evaluation of the footwear impact on the feet health status. It can be used by specialists in orthopaedics and in footwear design and technology. Its main objective is to help increase the life quality for everyone.
Interpretarea datelor obţinute se face prin calcularea scorului general care poate avea valori între 0 şi 100. Cu cât scorul obţinut are valoare mai mică, cu atât starea de sănătate a picioarelor este mai bună, iar dacă scorul se apropie de 100, starea de sănătate a picioarelor este precară. Se pot calcula şi scoruri pentru fiecare domeniu, putându-se astfel identifica cu precizie influenţa fiecărui domeniu.

\section{CONCLUZII}

În concluzie, chestionarul ESP este un instrument util în evaluarea sănătăţii extremităţii membrelor inferioare. Totodată, poate fi utilizat în evaluarea impactului încălţămintei asupra stării de sănătate. Este un instrument care poate fi utilizat de specialiştii în ortopedieşiîn tehnologia şi proiectarea încălţămintei. Obiectivul principal este acela de a ajuta la îmbunătăţirea calităţiivieţii pentru fiecare.

\section{REFERENCES}

1. Walmslay, S., Williams, E.A., Ravey, M., Graham, A., The rheumatoid foot: a systematic literature review of patientreported outcome measures, J Foot Ankle Res, 2001, 3, 12, doi:10.1186/1757-1146-3-12.

2. Roddy, E., Revisiting the pathogenesis of podagra: why does gout target the foot?, J Foot Ankle Res, 2011, 4, 13.

3. Roddy, E., Zhang, W., Doherty, M., Are joints affected by gout also affected by osteoarthritis?, Ann Rheum Dis, 2007, 66, 1374-1377.

4. Katsilambros, N., Dounis, E., Tsapogas, P., Tentolouris, N., Atlas of the Diabetic Foot, John Wiley \& Sons, Ltd., 2003.

5. Meenan, R.F., Gertman, P.M., Mason, J.M., Measuring health status in arthritis: the Arthritis Impact Measurement Scales, Arthritis Rheum, 1980, 23, 146.

6. Wallston, K.A., Brown, G.K., Stein, M.J. et al., Comparing the short and long versions of the Arthritis Impact Measurement Scales, J Rheumatol, 1989, 16, 1105.

7. Bergner, M., Bobbitt, R.A., Pollard, W.E. et al., The sickness impact profile: validation of a health status measure, Med Care, 1976, 14, 57.

8. Budiman-Mak, E., Conrad, K.J., Roach, K.E., The Foot Function Index: a measure of foot pain and disability, J Clin Epidemiol, 1991, 44, 561.

9. Johan, N.A., Liang, M.H., Daltroy, L., Rudicel, S., Richmond, J., American Academy of Orthopaedic Sugeons Lower Limb Outcomes Assessment Instruments. Reliability, validity and sensitivity to change, J Bone Joint Surg Am, 2004, May, 86-A(5), 902-9.

10. Bellamy, N., Buchanan, W.W., Goldsmith, C.H. et al., A health status instrument for measuring clinically important patient relevant outcomes following total hip or knee arthroplasty in osteoarthritis, J Orthop Rheumatol, 1988, 1, 95.

11. Melzack, R., The McGill Pain Questionnaire: major properties and scoring methods, Pain, 1975, 1, 277.

12. Bennett, P.J., Patterson, C., Wearing, S., Baglioni, T., Development and Validation of a Questionnaire Designed to Measure Foot-Health Status, J Am Podiatr Med Assoc, 1998, 88, 9, 419-428.

13. Farndon, L., Barnes, A., Littlewood, K., Harle, J., Beecroft, C., Burnside, J., Wheeler, T., Morris, S., Walters, S., Clinical audit of core podiatry treatment in the NHS, J Foot Ankle Res, 2009, 2, 7, doi:10.1186/1757-1146-2-7, http://www.jfootankleres.com/content/2/1/7.

14. Iovan-Dragomir, A., Foot Comfort (in Romanian), Ed. Performantica, ISBN 978-973-730-922-8, lasi, 2012.

Article received/Data primirii articolului: 27.10.2014

Accepted/Acceptat la data: 20.11.2014 